\title{
PRIVATE MILITARY CONTRACTORS, WAR CRIMES AND INTERNATIONAL HUMANITARIAN LAW
}

\section{Chukwuma Osakwe, Nigerian Defence Academy, and Ubong Essien Umoh, University of Uyo}

\begin{abstract}
The end of the Cold War witnessed the growth and spread of legally established private military contractors (PMCs) playing largely undefined roles in wars, international security and post-conflict reconstruction. The operations of PMCs in Iraq and Afghanistan in the $21^{\text {st }}$ century have been marked by gross human rights abuses and poor treatment and torture of prisoners of war (POWs). Indeed, PMCs are likely to step outside their contractual obligations and commit criminal acts. This article adds to the literature on the subject by arguing that the elusiveness of PMCs' individual or corporate responsibility for war crimes presents one of the greatest challenges for international humanitarian law (IHL). This presents a dilemma for IHL, which seeks to address individual offences. The situation becomes even more complicated when non-governmental organisations (NGOs) and multinational corporations (MNCs) are involved in the use of PMCs.
\end{abstract}

\section{Introduction}

Security and military-related services have largely remained the preserve of the state. At the end of the Cold War, a large number of trained soldiers were made redundant. As such most states outsourced most states outsourcing some of their defence and security functions to PMCs principally for cost-effective and sometimes political considerations. This invariably resulted in an unprecedented upsurge in the privatisation of the conduct of war carried out by $\mathrm{PMCs}^{1}$ with their services often integrated into the operating procedures of government, international organisations, and multinational companies undertaking a range of activities that previously would have been the responsibility of state militaries. The $21^{\text {st }}$ century

Scientia Militaria, South African Journal of Military Studies, Vol 42, $\mathrm{Nr} 1,2014$, pp. 64-79. doi : $10.5787 / 42-1-1081$ has witnessed a burgeoning growth in PMC deployed in combat zones of Iraq and Afghanistan. ${ }^{2}$ Such contractors have been known to play decisive roles in armed conflicts, with their presence sometimes 
determining the outcome of the conflict. Even though PMCs are not relatively new to international security, they are increasingly being recognised by governments, civil societies and international organisations as legitimate actors that can have an influence on the outcome of a conflict. Given the reality that PMCs could be involved in criminal acts during warfare, the elusiveness of their individual or corporate responsibility for war crimes presents one of the greatest challenges to international humanitarian law.

\section{Historical role of PMCs in armed conflicts}

PMCs are individuals or firms that provide international services traditionally provided by national militaries. PMCs are found to operate in situations of interstate and intrastate armed conflicts, either hired by a state actor party to the conflict, a non-state actor or by multinational organisations seeking protection of operations in a conflict zone. These contractors have been known to operate in large conglomerates thereby attracting the nomenclature of a company. To this end, they have also been referred to as 'private military companies'(PMCs). In popular media parlance, PMCs are occasionally referred to as 'military firms', 'military service providers' (MSPs), 'privatised military firms' (PMFs), 'transnational security corporations' (TSCs), and 'security contractors' (SCs). Carlos Ortiz defines private military companies as:

Legally established international firms offering services that involve the potential exercise of force in a systematic way and by military or paramilitary means, as well as the enhancement, the transfer, the facilitation, the deterrence, or the defusing of this potential, or the knowledge required to implement it, to clients. ${ }^{3}$

Ortiz's definition, which appears too broad and inclusive, views such companies and their contractors as international agents for the provision of military and security services. Some literature on the subject distinguishes three basic categories of PMCs: mercenaries, military contractors and security contractors based on whether they provide combat service, military training and strategic advice, or logistics and technical support. ${ }^{4}$ Another classification is given by Peter Singer, ${ }^{5}$ based on PMCs' functional capabilities, namely military provider contractors, consulting contractors and support contractors. Military provider contractors concentrate on tactical situations, often participating directly in actual conflict. Consulting contractors focus on building capabilities within the client's military or civil defence forces, while support contractors contribute many forms of nonlethal assistance to military forces in the field. ${ }^{6}$ The Pacific Architects and Engineers (PAE), for instance, were contracted in the 1990s to receive and manage logistic 
resources donated by the international community on behalf of the Economic Community of West African States Monitoring Group (ECOMOG) in Liberia and Sierra Leone. ${ }^{7}$

Attractive as the classification of PMCs might seem, in reality, most of these contractors provide functions that overlap established categories. Currently, PMCs carry out diverse activities, which cut across military operational support, military advice, logistical support, security services and crime prevention. Military advice involves providing training for state military forces, including special forces, covering weapons, tactics and force structure. Logistical support covers a whole range of services from supplying equipment to protecting humanitarian assets on the ground and helping to re-establish public infrastructure. Security services are directed at the commercial market and include guarding company assets and personnel. Crime prevention is also directed at the commercial market, but covers extortion and fraud as well. ${ }^{8}$ Acknowledging the expanded responsibilities of PMCs, the study being reported however dealt with the category of PMCs that carry out exclusive combat functions and operate predominantly in combat zones.

The privatisation of military force and the participation in armed conflicts of persons who are not officially members of the regular armed forces is nothing new.It is rooted in the age-old practice of 'hire to fire' where mercenaries are employed in armed conflicts. Ancient Egyptian armies hired the Nubians who were famous for their skill and precision with the bow. ${ }^{9}$ In a similar fashion, the armies of Alexander the Great, ancient Rome, the Swiss Guard, and Gustavus Adolphus employed large numbers of individuals motivated by adequate pay and steady work. ${ }^{10}$ Military history has recorded a strong role for private actors in military affairs firmly rooted in mercenary practice. Mercenaries, privateers and chartered companies have been an integral part of the international order. It is therefore not surprising that Nicollo Machiavelli in his writings warned against relying on mercenaries. ${ }^{11}$ Although this evidence strongly challenges the traditional perception of Max Weber's adherents that the state has the monopoly on violence, ${ }^{12}$ it is logical to assert that where the state chooses to outsource some of its security functions, it still holds a monopoly on violence.

Given this background, it is likely that the commercialisation and internationalisation of violence began with the commercialisation of war in Northern Italy as early as the eleventh century. ${ }^{13}$ During this period, military power was commercialised, democratised and internationalised. ${ }^{14}$ The Dutch and English East India Companies enlisted European mercenaries to protect their outposts from attack. In Nigeria, for instance, the 1886 Royal Niger Company Army was a mercenary army for the Royal Niger Company. In time, however, it became among 
other things, a new army for the Queen and the British government's imperial system in the nineteenth century. ${ }^{15}$ It seems, nonetheless, that it was with the arrival of the nation-state, commencing with the French Revolution of 1789, that the general population questioned the right of such actors to exist. ${ }^{16}$ Christopher Kinsey argues further that:

The French Revolution marked the start of the rise of national state armies that required huge bureaucracies to run them, a national population willing to fight, and huge amounts of resources to sustain them in the field. In this environment, mercenaries were very soon marginalised as their usefulness to politicians and military commanders rapidly vanished. ${ }^{17}$

From the close of the nineteenth century to the Cold War period, the use of mercenaries for state security services seems to have declined greatly. Wars became wars between nations, fought by the citizens of those nations, as opposed to between monarchs with private armies. At the beginning of the nineteenth century, nationalism, which the French Revolution galvanised, enabled the state to centralise military power under its authority, while removing mercenary forces from the domestic scene. This does not imply that states completely stopped using mercenaries beyond their borders; it meant that their relevance was greatly challenged.

After the Second World War (1939-1945), the need to fight proxy wars, which was the hallmark of the Cold War period, significantly enhanced the need to engage the services of mercenaries. ${ }^{18}$ The proxy wars that were fought in various 'Third World' countries of Asia, Africa and the Far East during the Cold War were marked by the use of mercenaries especially by the US, France and Britain. Mercenaries of European extraction participated in various postcolonial wars in Africa, such as the Congo, Angola and Sierra Leone. There has been extensive documentation on the use of mercenaries by Nigeria and Biafra alike during the Nigerian Civil War (1967-1970). ${ }^{19}$ By the mid-1980s, however, PMCs started to transform themselves into properly structured corporate entities with the term 'PMCs' increasingly coming into use and replacing the word 'mercenary'. ${ }^{20}$ The permanent nature of these corporate entities was seen as a key shift away from earlier ad hoc mercenary organisations. Throughout the 1990s, PMCs driven by business profit, gradually established themselves as commercial enterprises detached from any involvement with governments except when their interests converged. According to Christopher Kinsey:

By the 1980s, PMCs had started to transform their legal personality to take advantage of the commercial opportunities that were now 
starting to appear in many parts of the developing world. By the early 1990s, they were starting to operate openly for government agencies and multinational corporations, undertaking a range of security related tasks from military training to supplying military equipment. $^{21}$

PMCs have not only been employed by state actors but also by non-state actors such as international organisations (IOs), multinational corporations (MNCs) and even some international non-governmental organisations (INGOs). The United Nations (UN), the African Union (AU) and the European Union (EU) have made extensive use of PMCs. Given the fact that most Third World countries have been turned into a 'military arena',22 a corresponding demand for professional armed security was thus created. In this regard, PMCs have carried out operations from as far as Angola to Croatia and Columbia to Papua New Guinea. Different PMCs have operated on almost every continent except Antarctica. ArmorGroup, for example, employs 4000 people in 38 countries, ${ }^{23}$ while Military Professional Resources Inc (MPRI) employs over 1000 people and operates in every region of the world. ${ }^{24}$ Hart Group was contracted by the government of Puntland, a quasi-state that emerged after Somalia had fractured, to undertake coastal patrols on its behalf. ${ }^{25}$ With the outbreak of the second Gulf War in 2003, a number of PMCs such as Olive Security, Erinys International, Rubicon and Control Risks Group secured contracts to provide security in Iraq. In the first Gulf War, the ratio of US troops on the ground to private contractors was 50:1. By the second Gulf War, that figure had increased dramatically to $10: 1$, which was also the case in terms of the interventions in Bosnia and Kosovo. ${ }^{26}$ In the civil war in the Congo, Geolink gave military support to Mobutu's regime, and in the case of the Angolan and Sierra Leone civil wars, Executive Outcomes greatly enhanced the government's ability to commit the 'rebels' to the negotiation table.

Sometimes, PMCs are used as a smokescreen for the major powers that do not want to be seen as interfering in either internal affairs of nations or the affairs of a region or sub-region. For example, the American PAE operated with peace support forces in the Liberian and Sierra Leonean civil wars of the 1990s. To make their appearance more suspicious, their roles were largely undefined and overlapping. They inter alia -

- $\quad$ assisted the Nigerian Contingency (NIGCON) in Liberia to convey arms and ammunition from disarmament sites to ECOMOG headquarters;

- $\quad$ constructed road blocks used during the disarmament exercise;

- $\quad$ repaired roads; 
- provided petrol and oil lubricants for NIGCON logistics;

- $\quad$ aided in medical evacuation; and

- $\quad$ provided Motorola sets for communication. ${ }^{27}$

The specific role of PMCs in armed conflicts have been complicated further by the overlapping nature of peacekeeping, peace-enforcement, peace-support and humanitarian rescue operations.

\section{War crimes in the conduct of warfare}

War crimes do not connote the idea that going into war (jus ad bellum) is a crime but rather that there are some actions that are carried out during war (jus in bello), which constitute crime in their context. International law on its own does not outlaw war - although attempts have been made in the past to outlaw $\operatorname{war}^{28}$ - but rather uses various regulations, which must be strictly followed to make the objective of war, which is 'victory' and 'peace', attainable. Few scholars, like James T. Shotwell, argue that war on its own is an instrument of criminal aggression, a concentration of all human crimes, ${ }^{29}$ and as such, the use of the term 'war crimes' duplicates irony. However, other scholars, like Eagleton and Quincy Wright, argue that war at various times have performed functions that have been socially desirable, remedied unjust situations, settled disputes and enforced rights. ${ }^{30}$ Quincy Wright even contends that war is a legally accepted means of settling disputes between and among states. ${ }^{31}$ An acute dilemma thus seems to be evident in the discourse since a state could have a just reason ${ }^{32}$ for starting or engaging in war, but in the course of the war, carries out actions that can be strictly categorised as being 'unjust'.

The British law-of-war manual sees war crimes as:

... violations of the laws or customs of war, including but not limited to murder, the ill-treatment or deportation of civilian residents of an occupied territory to slave labour camps, the murder or ill-treatment of prisoners of war, the killing of hostages, the wanton destruction of cities, towns and villages, and any devastation not justified by military necessity. ${ }^{33}$

War crimes are sometimes part of instances of mass murder and genocide on political, racial or religious grounds. These crimes are more broadly covered under IHL and are described as 'crimes against humanity'. Even failure to take the necessary action to prevent or end violations of the laws or customs of war would itself constitute a war crime. ${ }^{34}$ Furthermore, war crimes include violations of established protections of the laws of war, but also include failures to adhere to 
norms of procedure and rules of battle, such as attacking those displaying a flag of truce, or using that same flag as a ruse of war to mount an attack. Protocol I, Article 42 of the Geneva Conventions explicitly forbids attacking parachutists who eject from damaged airplanes, and surrendering parachutists once landed. ${ }^{35}$

Technically, war crimes are defined in the statute that established the International Criminal Court (ICC), which includes grave breaches of the Geneva Conventions, such as -

- wilful killing, or causing great suffering or serious injury to body or health;

- $\quad$ torture or inhumane treatment;

- unlawful wanton destruction or appropriation of property;

- $\quad$ forcing a prisoner of war to serve in the forces of a hostile power;

- $\quad$ depriving a prisoner of war of a fair trial;

- unlawful deportation, confinement or transfer; and

- taking hostages. $^{36}$

However, controversy does not arise as to what war crimes should be defined as but as to who should define it. If Hitler's Germany had won WWII, would there have been a Nuremberg Tribunal? Why was a similar tribunal not set up after the 1968 My Lai massacre in Vietnam?

\section{International humanitarian law and war crimes}

International humanitarian law (IHL) is also known as the law of war or the law of armed conflict. It seeks to interrogate moral actions (jus in bello) carried out by belligerents during war. It is a part of international law, embodying a set of rules which seek, for humanitarian reasons, to limit the effects of armed conflict. While international law addresses states only, IHL in principle is directed at individuals. It protects people who are not or who are no longer participating in the hostilities, and restricts the means and methods of warfare. It applies only to armed conflict and seeks a balance between the military requirements of states and humanitarian concerns.

Beyond protecting persons in armed conflicts, IHL also places a restriction on the means of warfare - in particular weapons - and the methods of warfare, such as military tactics. ${ }^{37}$ To this end, IHL has banned the use of many weapons, including exploding bullets, chemical and biological weapons, blinding laser weapons and anti-personnel mines. IHL prohibits all means and methods of warfare which fail to 
discriminate between those taking part in the fighting and those, such as civilians, who are not. It is aimed at mitigating unnecessary suffering during armed conflict.

The concept of the 'laws of war' is made possible in order to regulate the conduct of individuals, nations and other agents in war and to mitigate the worst effects of war. To this end, laws of war are intended to mitigate the 'evils' of war by:

- protecting both combatants and non-combatants from unnecessary suffering;

- $\quad$ safeguarding certain fundamental human rights of persons who fall into the hands of the enemy, particularly prisoners of war, the wounded and sick, and civilians; and

- $\quad$ facilitating the restoration of peace. ${ }^{38}$

Besides bringing wars to a quick end, such laws help to restrict wars to their political objective and also to protect people and property from unnecessary destruction and hardship. Among other issues, the laws of war address -

- declaration of war, acceptance of surrender and the treatment of prisoners of war;

- $\quad$ military necessity along with distinction and proportionality; and

- the prohibition of certain inhumane weapons which cause unnecessary suffering. 39

It is a violation of the laws of war to engage in combat without meeting certain requirements, among them the wearing of a distinctive uniform or other distinctive signs visible at a distance, and the openly carrying of weapons.

The necessary condition for war crimes is that, first, there exists a law of armed conflict. The United Nations War Crimes Commission describes the laws and customs of war as 'the rules of international law with which belligerents have customarily, or by special convention, agreed to comply in case of war'. ${ }^{40}$ When such 'special conventions' under the 'rules of international law' are violated, a war crime can be said to have been committed. This implies that every violation of the laws of war is a war crime. ${ }^{41}$ The International Committee of the Red Cross opines that 'serious violations of international humanitarian law constitute war crimes'. ${ }^{4}$ What constitutes 'serious violations' continues to undergo a serious introspection into its core assumptions. It suggests that, after all, some crimes can be committed in war which are not 'serious' enough to be classified as war crimes. Yoram Dinstien argues that such an assertion has never been supported in actual state practice. ${ }^{43}$ What has been accepted, interpreted and tagged as war crimes tend to be 
highly subjective. This has informed Garry Solis' position that 'war crimes' is an elastic rubric, and necessarily so. ${ }^{44}$

\section{PMCs and war crimes: Aspects of challenge for international humanitarian law}

The traditional notion that war crimes were originally conceived as a concept relating to the armed forces fighting in a war has been seriously challenged by the overwhelming involvement of PMCs hired to conduct offensive military operations. Private military personnel, unlike state armed forces, seem to occupy a relatively ambiguous legal status within the context of IHL. Their actions are often marked by impunity involving violation of the laws of war, ranging from participation in war crimes and crimes against humanity, to the abuse of prisoners and shooting indiscriminately at civilians. ${ }^{45}$ The legal background against which PMCs seem to operate and which they seem to enjoy has resulted in an almost complete absence of legal prosecution against war crimes. This does not in any way suggest that PMCs are more likely to engage in gross armed misconduct and war crimes than state armed forces.

PMCs have been accused of having committed or assisted in various crimes against civilians and detainees, especially during the second Gulf War. The accountability gap of PMCs was revealed in the 2004 incidents at Abu Ghraib detention facility in Iraq, which recorded gross abuse of human rights by CACI - an American-hired PMC. Evidence records that, while the state military officers found by a military investigation to have participated in the abuse of detainees were subjected to court martial and sentenced to prison, none of the employees of two PMCs implicated in the abuses were charged with any crime. ${ }^{46}$ Apart from the abuse of prisoners at Abu Ghraib, on 16 September 2007, employees of Blackwater USA, while escorting a US diplomatic convoy for the State Department, killed about 17 Iraqi civilians when engaged in a fire fight in Nisour Square in Baghdad city. ${ }^{47}$ In Sierra Leone, Executive Outcomes carried out air strikes ensuing huge collateral damage. ${ }^{48}$ These and many more instances point to the fact that international law is notoriously difficult to enforce ${ }^{49}$ and in most instances, has been scrupulously observed. $^{50}$

In reality, all serious violations of IHL are war crimes subject to universal jurisdiction. As such, it is expected that persons indicted could be prosecuted in any state or before any international tribunal that has jurisdiction. However, a basic challenge for IHL is that not all states have adopted legislation enabling them to prosecute persons on the basis of universal jurisdiction. Even when all states adopt such legislation, would the prosecution of private military personnel for crimes 
committed abroad be based on the nationality of the offender or on the basis of universal jurisdiction? Although, in theory, all contractors remain subject to the provisions of extra-territorial jurisdiction of their respective home countries, in most cases civilian law enforcement agencies seldom conduct criminal investigations in war zones. Moreover, the issue of the collection and hearing of evidences from another country poses a challenging, daunting and expensive task. It is therefore not surprising that during the first five years of US occupation of Iraq, no PMC was prosecuted for acts of violence against locals, including contractors implicated in the Abu Ghraib torture scandal. ${ }^{51}$

Acknowledging that PMCs are liable to commit criminal acts during warfare, Chia Lehnardt ${ }^{52}$ has identified the doctrine of command responsibility and the issue of superior orders as two technical aspects relating to war crime trials of PMCs that may be quite challenging. As it bothers state armed forces, commanders are usually held responsible for crimes they have ordered to be committed. Moreover, commanders and superiors are criminally responsible for war crimes committed by their subordinates if such commanders or superiors knew, or had reason to know, that the subordinates were about to commit or were committing such crimes, and did not take all necessary and reasonable measures to prevent them. ${ }^{53}$ Furthermore, commanders are also liable if, once war crimes have been committed by their subordinates, they do nothing to investigate, report or punish the persons responsible. It is generally accepted that such superiors can be civilian persons provided that they are effectively acting as military commanders. ${ }^{54}$ Extending the limits of this position, one could infer with a great deal of caution that the killing and displacement of thousands of civilians by the United States under the ambiguous term 'foreign policy' could attract war crime penalties for the leaders. In this regard, leaders like the two George Bushes of the United States, whose policies led to several war crimes, might be branded war criminals. It is not surprising that Edward Herman argues that:

Because of its power and global interests U.S. leaders have committed crimes as a matter of course and structural necessity. A strict application of international law would ... have given every U.S. president of the past 50 years a Nuremberg treatment. ${ }^{55}$

A peculiar issue that arises as regards the operations of PMCs is the difficulty of identifying an overall commander who should bear responsibility for criminal acts carried out during field operations. Should it be the chief executive officer (CEO) of the PMC or the highest ranking field officer of the PMC involved in military or security operations? If a commander cannot be identified in the command hierarchy, then it is expected that the perpetrator of the crime should be 
arraigned in the context of the time and circumstances during which the crime was committed. In this view, an individual state official who contracted the PMC should be responsible for war crimes committed by a member of the PMC. This would make such an official or contracting government to take full control of the actions of such private military men hired during an armed conflict.

As far as obeying orders is concerned, it is widely acknowledged in principle that obeying a superior order does not relieve a subordinate of criminal responsibility if the subordinate knew that the act ordered was unlawful or should have known because of the manifestly unlawful nature of the act. Can PMCs be submerged in this commander-subordinate relationship? In principle, PMCs are by definition only in a contractual relation with the hiring actor. Thus, their acts are not in principle acts of state but acts of various actors on the international stage. The problem of accountability becomes even more complex when private military contractors are used by international organisations, such as the UN, the EU or NATO. In this case, their conduct may call into play the still elusive concept of institutional responsibility of intergovernmental organisations.

State actors could also act as a stooge in the appropriate application of international humanitarian laws on operations of PMCs. For instance, the United States, which has the largest number of PMCs, is not a signatory to the ICC. ${ }^{56}$ Although reasons abound for this decision, it is not unconnected with the enormous global 'police' responsibilities of the United States that create unique circumstances at the 'boot lace' level of operations. As submitted by Senator Hilary Clinton in 2005 , “... we are more vulnerable to the misuse of an international criminal court because of the international role we play and the resentments that flow from that ubiquitous presence around the world". ${ }^{57}$ This questions the status of IHL given the fact that its content is not recognised by a number of states and especially a super power like the United States. Moreover, IHL is interpreted very differently by some states, and at times are honoured more in breach than in fact.

Since wars carried out by PMCs are contractual, it is likely that PMCs could frequently hide under such powerful governments to carry out criminal acts during warfare. This is further accentuated by the reality that the operations of PMCs are largely surreal and covert in nature and their activities highly unpredictable. Some PMCs seem to operate more as "special forces ${ }^{58}$ with their employment in war situations premised on the notion that "there are some itches that only Special Forces can scratch". ${ }^{59}$ Should PMCs operate as Special Forces in a complex security environment, then it is likely that their contractual obligations and desire to maximise profit may not always align with IHL. While few have argued that the prospect of extraordinary monetary gain remains a central motivator for 
individuals to sign on with $\mathrm{PMCs},{ }^{60}$ a direct causal link has not been established between PMC profit seeking and PMCs' human rights violations. However, it is likely that in the quest for profit, human rights abuse might become inevitable. This does not in any way suggest that national armies are less likely to violate human rights while carrying out the same military operations. Indeed, Volker Franke and Marc von Boemcken ${ }^{61}$ argue empirically that most PMCs display attitudes comparable to those of military professionals, adhering to high levels of professionalism and ethical conduct and motivated largely by altruistic factors.

\section{Conclusion}

As regards criminal acts carried out during warfare, the field activities of PMCs seem to be marred by a lack of satisfactory legislative regulation and enforceable jurisdiction. PMCs seem to operate in a legal vacuum with their operational activities relatively unregulated. This has compelled the need to examine the challenges the expanding role PMCs have on IHL. PMCs operate in a highly competitive global marketplace and often tend to explore operational options that would gain them the quickest victory with the lowest casualty cost on their side. In most cases, such operational options are not devoid of war crimes. War crimes carried out by PMCs remain a sensitive aspect that IHL is yet to tackle fully. Though there is specific reference to mercenaries in IHL, there is no such reference to PMCs in IHL treaties nor are they specifically regulated in customary international law. The absence of a discrete regulation of PMCs does not mean that there is no law applicable to them. The difficulty in applying IHL in terms of war crimes carried out by PMCs is accentuated by the burden of the command-subordinate structure buried beneath the avalanche of contractors and subcontractors.

\section{Endnotes}

1 Singer, PW. Corporate warriors: The rise of the privatised military industry. London: Cornell University Press, 2003, 11. Technically, PMCs should be differentiated from other non-military/non-combat private contractors who carry out defence-related roles but do not possess exclusive combat capabilities.

${ }^{2}$ According to the US Department of Defense, the number of armed security contractors had increased by 140\% from 5481 in September 2007 to 13232 in June 2009. In Afghanistan, the increase was even steeper. Between December 2008 and September 2009, the number of armed security contractors increased by $236 \%$ from 3184 to 10 712. See Schwartz, M. "The 
Department of Defense's use of private security contractors in Iraq and Afghanistan: Background analysis, and options for congress". Congressional Research Service 7-5700. $19 \quad$ January 2010. $\langle$ http://www.fas.org/sgp/crs/natsec/R40835.pdf > Accessed on 20 January 2014.

${ }^{3}$ Ortiz, C. Private armed forces and global security: A guide to the issues. Oxford: Praeger, 2010, 48.

${ }^{4}$ Cleaver, G. "Subcontracting military power: The privatization of security in contemporary sub-Saharan Africa". Crime, Law and Social Change 33/1\&2. 2000. 131-149. See also Adams TK. "The new mercenaries and the privatization of conflict". Parameters Summer 1999. 103-116. See also Brooks, D. "Messiahs or mercenaries? The future of international military services". International Peacekeeping 7/4. 2000. 129-144.

${ }^{5}$ Singer op. cit.

${ }^{6}$ Ibid., p. 26.

${ }^{7}$ Oni, SK. The Nigerian Army in ECOMOG operations: Liberia and Sierra Leone. Ibadan: Sam Bookman, 2002, 244.

${ }^{8}$ Kinsey, C. Corporate soldiers and international security: The rise of private military companies. London: Routledge, 2006, 17.

${ }^{9}$ The Nubians were also hired by the Carthaginian General Hannibal in the Punic Wars (264 BC - $146 \mathrm{BC}$ ) to fight against the Romans for their horsemanship.

${ }^{10}$ Kidwell, DC. "Public war, private fight? The United States and private military companies". Global War on Terrorism Occasional Paper 12, Combat Studies Institute Press, Kansas, 2005, 3.

${ }^{11}$ Machiavelli, N. The prince. Translated by D Donno. New York: Bentam Dell, 1966.

${ }^{12}$ Max Weber saw the state as a human community that successfully claims the monopoly of the legitimate use of physical force within a given territory. See Weber, M. "Politics as a vocation". In From Max Weber: Essays in sociology, translated by HH Gerth \& C Wright Mills. New York: Oxford University Press, 1946.

${ }^{13}$ Thomson, J. Mercenaries, pirates, and sovereigns. Princeton, NJ: Princeton University Press, 1994, 21.

${ }^{14}$ Ibid., p. 41.

${ }^{15}$ Ukpabi, S. Mercantile soldiers in Nigerian history: A history of the Royal Niger Company Army, 1886-1900. Zaria: Gaskiya Corporation, 1987.

${ }^{16}$ Kinsey op. cit., p. 34.

${ }^{17}$ Ibid., p. 43.

${ }^{18}$ Singer op. cit., p. 61.

${ }^{19}$ See Madiebo, AA. The Nigerian Revolution and the Biafran War. Enugu: Fourth Dimension, 1980. See also De St. Jorre, J. The Nigerian Civil War. London: 
Hodder\& Stoughton, 1972. See also Forsyth, F. The making of an African

legend: The Biafra story. Harmondsworth: Penguin Books, 1977.

${ }^{20}$ Kinsey op. cit., p. 37.

${ }^{21}$ Ibid., p. 55.

${ }^{22}$ According to Lasswell and Kaplan, "an arena is military when the expectation of violence is high; civil when the expectation of violence is low". See Lasswell, HD \& Kaplan, MA. Power and security. New Haven, CT: Yale University Press, 1950, 252.

${ }^{23}$ ArmorGroup. Single source solutions for global security risk management. London, 2001.

${ }^{24}$ See Kinsey op. cit., p. 2.

${ }^{25}$ Singer op. cit., p. 11.

${ }^{26}$ Rohatyn, F \& Stranger, A. "The profit motive goes to war". The Financial Times. 17 November 2004.

${ }^{27}$ Oni op. cit., pp. 85, 87, 107, 197, 239.

${ }^{28}$ One of such attempt was the Kellog-Brian Pact of 1928 , which sought to outlaw war as an instrument of foreign policy and as a means of settling disputes between states.

${ }^{29}$ Shotwell, JT. War as an instrument of national policy. New York: Harcourt Brace, $1929,15$.

${ }^{30}$ Eagleton, C. "Analysis of the problem of war". In Palmer, ND \& Perkins, H (eds), International relations: The world community in transition, Delhi: AITBS Publishers, 2007, 191.

${ }^{31}$ Wright, Q. A study of war. Chicago, IL: University of Chicago Press, 1942.

${ }^{32} \mathrm{~A}$ war fought as a last resort to defend oneself or repel attack is militarily regarded as a 'just war'. See Walzer, M. Just and unjust wars: A moral argument with historical illustrations. New York: Harper Torchbooks, 1977. See also Johnson, JT. Just war tradition and the restraint of war: A moral and political inquiry. Princeton: Princeton University Press, 1981.

${ }^{33}$ UK Ministry of Defense. The Manual of Law of Armed Conflict. Oxford: Oxford University Press, 2004, par. 16.21, at 422.

${ }^{34}$ Field Manual 27-10. The law of land warfare. Washington: GPO, 1956, par. 499 at 148.

${ }^{35}$ United Nations War Crimes Commission. History of the United Nations War Crimes Commission and the development of the laws of war. London: His Majesty Stationary Office, 1948, 24.

${ }^{36}$ Keenan, JB \& Brown, BF.Crimes against international law. Chicago, IL: Chicago University Press, 1950, 112.

${ }^{37}$ International Committee of the Red Cross, "Advisory service on international humanitarian law, International Committee of the Red Cross 07/2004". <http://www.icrc.org/pdf > Accessed on 15 October 2012.

${ }^{38}$ Dinstien, Y. The conduct of hostilities under the law of international armed conflict. New York: Cambridge University Press, 2004, 229. 
39 Solis, GD. The law of armed conflict: International humanitarian law in war. Cambridge: Cambridge University Press, 2010, 304.

${ }^{40}$ International Committee of the Red Cross. Protocol additional to the Geneva Conventions of 12 August 1949, and relating to the protection of victims of international armed conflict (Protocol I). Geneva.

${ }^{41}$ Kalshoven, F. Constraints on the waging of war. Geneva: International Committee of the Red Cross, 1987, 30.

${ }^{42}$ Ibid., p. 22.

${ }^{43}$ Dinstienop. cit., p. 234.

${ }^{44}$ Solis op. cit., p. 308.

${ }^{45}$ Lehnardt, C. "Individual liability of private military personnel under international criminal law". European Journal of International Law19/5. 2008. 1016.

${ }^{46}$ Spiegel, P. "No contractors facing Abu Ghraib abuse charges". Financial Times. 9 August 2005.

${ }^{47}$ Lehnardt op. cit., p. 1017.

${ }^{48}$ See Dickinson, LA. "Government for hire: Privatizing foreign affairs and the problem of accountability under international law". William and Mary Law Review 47/1. 2005. 213.

${ }^{49}$ Sabel, R. "Weapons to non-state armed groups - back to Westphalia?" Disarmament Forum 1. 2008. 5.

50 Morgenthau, HJ. Politics among nations: The struggle for power and peace ( $5^{\text {th }}$ ed). London: Alfred A. Knopf, 1978, 281.

${ }^{51}$ Franke, V \& Von Boemcken, M. "Private guns: The social identity of security contractors". The Journal of Conflict Studies 29. 2009.

${ }^{52}$ Lehnardtop. cit., pp. 1015-1034.

${ }^{53}$ Prevent Genocide International. "Rome Statute of the International Criminal Court". <www.preventgenocide.org/law/icc/statute/part-a.htm $>$ Accessed on

${ }^{54}$ Ibid. 12 October 2012.

${ }^{55}$ Herman, E. War crimes and the United States foreign policy. London: Macmillan, $1985,71$.

${ }^{56}$ The International Criminal Court is a permanent international criminal court, founded in 2002 by the Rome Statute to "bring to justice the perpetrators of war crimes, crimes against humanity, and genocide".

57"Remarks of Senator Hillary Rodham Clinton at German Media Prize Dinner" http://archive.today/Y6jHD. Accessed on 18 September 2012.

${ }^{58}$ Clancy, T \& Stiner, C. Shadow warriors: Inside the special forces. New York: GP Putnam's Sons, 2002, 55-56.

${ }^{59}$ General Bill Yarborough quoted in Clancy \& Stiner op. cit.

${ }^{60}$ Franke \& Von Boemcken op. cit. Both authors also argue in the same work that PMCs have been known to pay considerably higher wages than the military at the comparable skill level or rank. 
${ }^{61}$ Franke, V \& Von Boemcken, M. "Guns for hire: Motivations and attitudes of private security contractors". Armed Forces \& Society 37/4. July 2011. 725742. See also Franke \& Von Boemcken, "Private guns ..." op. cit. 